\title{
Fish Diversity of Jagadispur Reservoir, Kapilbastu District, Nepal-a Ramsar Site
}

\author{
Deependra Gautam ${ }^{1}$, Tej Bahadur Saund ${ }^{1}$ and Jiwan Shrestha ${ }^{2}$ \\ ${ }^{1}$ Central Department of Environmental Science, Tribhuvan University, Kirtipur, Kathmandu \\ ${ }^{2}$ Central Department of Zoology, Tribhuvan University, Kirtipur, Kathmandu \\ e-mail:hideepen@gmail.com
}

\begin{abstract}
A total of 2273 fishes were captured from Jagadispur reservoir, one of the Ramsar sites of Nepal using gill nets. Forty-two fish species belonging to 6 orders, 18 families and 34 genera were recorded during the investigation period from the reservoir and listed with their nomenclature and systematic position. Cypriniformes and Cyprinidae were the dominant Orders and family in terms of species composition as well as catch composition respectively. Nandus nandus was the most dominant fish species accounting $16.50 \%$ of the total catch which is an indication of deteriorating water quality. However, water quality parameters (surface water temperature: $20.7^{\circ} \mathrm{C}-31^{\circ} \mathrm{C}$; $\mathrm{pH}$ : $6.8-$ 7.6; dissolved oxygen: $5.2 \mathrm{mg} / \mathrm{l}-8.7 \mathrm{mg} /$; free carbondioxide: $11.1 \mathrm{mg} / \mathrm{l}-23.6 \mathrm{mg} / \mathrm{l}$; total hardness: $68.2 \mathrm{mg} / \mathrm{l}-137.5 \mathrm{mgl}$; total alkalinity: $69.6 \mathrm{mg} / \mathrm{l}-192 \mathrm{mg} / \mathrm{l}$ ) were observed within a desirable range supporting warm water fish species.
\end{abstract}

Key words: fish diversity, gill net, Ramsar site, reservoir, water quality

\section{Introduction}

Nepal is the second richest country in the world in freshwater resources occupying at least 5.5\% of its area with different types of wetlands (Shrestha 1981). Wetlands are areas where water is the primary factor controlling the environment and the associated plant and animal life. The Informal Wetland Group in Nepal at the first meeting on wetland management in Nepal (Shrestha and Bhandari, 1992) attempted to define wetlands as follows; "Wetlands represent landmass saturated with water due to high water table through ground water, atmospheric precipitation or inundation. It may be natural or artificial, permanent or temporary, static or flowing and fresh water or brackish water.”

Wetlands in Nepal constitute about 816954 ha of inland water resources comprising of rivers and streams (48.38\%), lakes $(0.61 \%)$, reservoirs $(0.18 \%)$, village ponds (0.80\%), marginal/swamps/Gholes (1.36\%) and irrigated paddy fields (48.71\%) (DoFD 2007).

The Ramsar Bureau has designated and listed the Beeshazar Tal (Lake) of Chitwan district, Ghodaghodi Tal of Kailali district and the Jagadishpur reservoir of Kapilvastu district of Nepal as Ramsar Sites in August
13, 2003. Moreover four new wetland sites, namely Rara Lake, Phoksundo Lake, Gokyo and Associated Lakes, and Gosainkunda and Associated Lakes have also been added in the Ramsar list (Kafe 2008).

Shrestha (2003) studied the fishes of Nepal from their recent taxonomic point of view and reported 186 species while Rajbansi (2005) prepared a checklist of Nepalese fishes from published literature and reported 187 species.

Ng and Edds (2004-2006) studied the fishes of Nepal and reported some new species. Therefore 184 fish species of Nepal increased to a total number of 199 as earlier identified two species (Batasio batasio and Pseudechenis sulcatus) have been abolished from the list of Shrestha (2003) (Saund \& Shrestha 2007). Shrestha (2008) has reported a total of 217 species from Nepal.

During the past 10 years, 14 new species have surfaced in the eastern Himalayas. As a result of this increase in ichthyological activity during 1998 to 2008, 7 new fish species have been reported from Nepal (WWF 2009). 
Very little research work has been done in this wetland site in the field of freshwater ecology. DNPWC/IUCN (2002) made a single survey in July 1997 and reported that the reservoir helds at least 25 fish species. Fishes are one of the major wetland resources harvested by the local populace living adjacent to the reservoir (DNPWC/IUCN 2002). For the sustainable management of the fish resources in the reservoir, the water quality of the reservoir, the types of fishes, their tolerance limits towards different water quality variables, potential threats to the fish resources and the harvesting rate of fishes should be known. The present investigation aims towards addressing these issues.

\section{Description of the study area}

The present study area, Jagadispur reservoir (225ha), lies in Niglihawa VDC, Kapilvastu district, Lumbini zone; $10 \mathrm{~km}$ north of Taulihawa, the district headquarter of Kapilvastu district, at geographical coordinates $27^{0} 35^{\prime} 00.0^{\prime \prime} \mathrm{N}$ and $83^{\circ} 05^{\prime} 00.0^{\prime \prime} \mathrm{E}$. The area is characterized by its low elevation (197m above mean sea level) experiencing tropical monsoon climate of hot, rainy summer and cool, dry winter (DNPWC/IUCN 2002).

The reservoir irrigates 6,200ha agriculture land of 18 VDCs and 1 municipality through one main canal, 16 sub-canals and 160 minor canals (Joshi 2006). The current uses of the reservoir include fishing, grazing, fuelwood and fodder collection and supply of water for irrigation (DNPWC/IUCN 2002).

Jagadispur reservoir was constructed over the location of the Jakhira Lake and agricultural land in the early 1970s and construction of a rock-fill dyke took place in the early 1980s. The water was fed from the nearby river known as Banganga. Water depth varies from $2 m-3 m$ to $5 m-7 m$ at the deepest area. The reservoir is surrounded by cultivated land and there are few smaller lakes known as the Sagarhawa and Niglihawa situated near its periphery (DNPWC/ IUCN 2002).

\section{Methodology}

Baseline information was collected from the study sites during January to December 2005 by conducting six field visits in January, March, May, July, September and November. Additional information was collected by consulting the related experts, local people, literature and maps of the research area.

For the present investigation, only three sampling sites were selected and designated as site I, site II and site III respectively (Fig. 1). These sites were chosen as they were netting places of local fishermen.

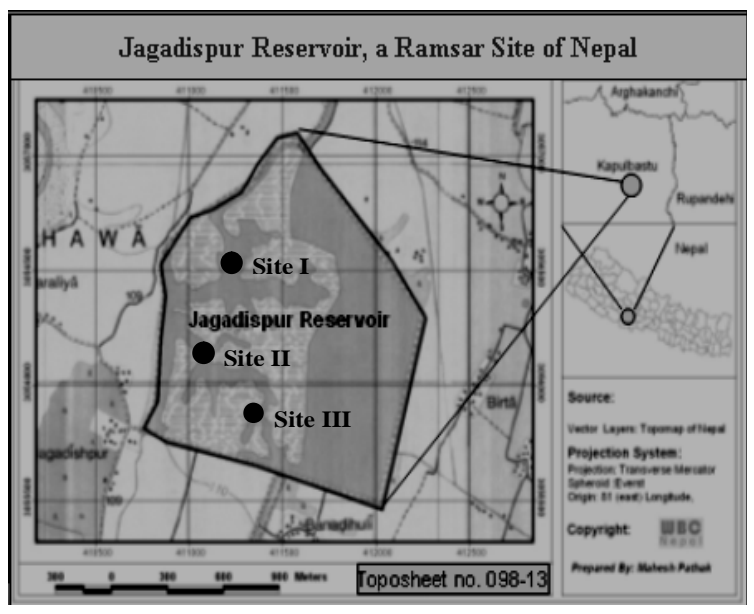

Fig. 1. Sampling sites in the study area

General description of the sampling sites Site I: Inlet region of the reservoir, which is dominated by flowing water and small patches of islands.

Site II:Main body of the reservoir, which contains deep pool of water with free floating vegetation.

Site III: Outlet region of the reservoir, which contains stagnant water with submerged aquatic vegetation.

\section{Water sampling and analyses}

Rubber tubes were used to reach the sampling sites and water samples (surface water) were collected with the help of sterilized sampling bottles. The parameters like depth, temperature, $\mathrm{pH}$ and transparency were measured immediately at the time of sampling and other parameters like dissolved oxygen, free carbon dioxide, alkalinity and hardness were measured within few minutes after collection of samples following the standard methods prescribed by APHA, AWWA and WEF (1998).

\section{Fish sampling and analyses}

A composite gill net formed from two sets of nets (Type 1- length: 50m, height: $1 \mathrm{~m}$ and mesh size: $0.5 \mathrm{inch}$ and 
Type 2- length: 50m, height: $1 \mathrm{~m}$ and mesh size: 1inch) attached linearly, was used for fish sampling. Three composite gill nets were used for each site. Certain fish species such as Amblypharyngodon mola and Mastacembelus armatus could be collected only in nets with mesh size of $0.5 \mathrm{inch}$. So, in order to sample majority of the fishes present in the reservoir, two sets of nets were used.

In the late evening, the composite gill net was fixed horizontally in the water body for overnight. Early morning the next day, the net was taken out of the water body and the fishes entangled in the net were collected. Two fishermen were hired for this purpose.

The collected fishes were counted on the spot and the samples of each species were preserved in 5\% formalin solution. The samples were then brought to the laboratory and identified to species level using taxonomic literature (Shrestha 1981, 1995, 2001 \& Jayaram 1999).

The catch compositions of individual fishes were determined using the following formula:

Catchcomposition by rumber $(\%)=\frac{\text { Totalcatch of mindin iduspecies } \times 100}{\text { Totalcatch of allpecies }}$

\section{Results and discussion}

Water quality was analyzed in order to identify how good was the water of the reservoir for fish production. The fluctuations in water quality parameters (transparency: $0.7 \pm 0.10 \mathrm{~m}$ and $20.10 \mathrm{~m}$; surface water temperature: $20.70 .76^{\circ} \mathrm{C}$ and $311.32^{\circ} \mathrm{C}$; $\mathrm{pH}$ : 6.80 .17 and 7.60.17; dissolved oxygen: $5.20 .10 \mathrm{mg} / \mathrm{l}$ and $8.70 .21 \mathrm{mg} /$ l; free carbondioxide: $11.10 .31 \mathrm{mg} / \mathrm{l}$ and $23.61 .80 \mathrm{mg} / \mathrm{l}$; total hardness: $68.26 .85 \mathrm{mg} / \mathrm{l}$ and $137.59 .24 \mathrm{mg} / \mathrm{l}$; total alkalinity: $69.66 .04 \mathrm{mg} / \mathrm{l}$ and $1924.39 \mathrm{mg} / \mathrm{l}$ ) were found to be within the desirable range to support good fish production. As such, Jagadispur reservoir possessed a great potential for fish production in cage culture. Thus, locals could benefit from its fish production potentiality (cage culture) without hampering its biodiversity.

Forty-two fish species belonging to 6 orders, 18 families and 34 genera were recorded during the investigation period, comprising of 38 indigenous and 4 exotic species. The details are given below:

\section{Systematic classification of fishes}

The identified fish species are classified after Jayaram (1999).

\section{Order: Beloniformes \\ Family: Belonidae}

Genus: Xenentodon Regan 1911

1. Xenentodon cancila (Hamilton-Buchanan) 1822

Order: Cypreniformes

Family: Balitoridae

Genus: Acanthocobatis Peters 1861

2. Acanthocobatis botia (Hamilton-Buchanan) 1822

Family: Cobitidae

Genus: Lepidocephalus Bleeker 1859

3. Lepidocephalus guntea (Hamilton-Buchanan) 1822

Family: Cyprenidae

Genus: Salmostoma Swainson 1839

4. Salmostoma bacaila (Hamilton-Buchanan) 1822

Genus: Catla Valenciennes 1844

5. Catla catla (Hamilton-Buchanan) 1822

Genus: Cirrhinus Cuvier 1817

6. Cirrhinus mrigala (Hamilton-Buchanan) 1822

7. Cirrhinus reba (Hamilton-Buchanan) 1822

Genus: Ctenopharyngodon Steindachner 1866

8. Ctenopharyngodon idella (Valenciennes) 1844

Genus: Cyprinus Linnaeus 1758

9. Cyprinus carpio Linnaeus 1758

Genus: Labeo Cuvier 1817

10. Labeo pangusia (Hamilton-Buchanan) 1822

11. Labeo rohita (Hamilton-Buchanan) 1822

Genus: Osteobrama (Heckel) 1842

12. Osteobrama cotio (Hamilton-Buchanan) 1822

Genus: Puntius (Hamilton-Buchanan) 1822

13. Puntius chola (Hamilton-Buchanan) 1822

14. Puntius sophore (Hamilton-Buchanan) 1822

Genus: Hypothalamichthys Bleeker 1859

15. Hypothalamichthys molitrix (Valenciennes) 1844

Genus: Aristichthys Oshima 1919

16. Aristichthys nobilis Richardson 1845

Genus: Amblypharyngodon Bleeker 1860

17. Amblypharyngodon mola (Hamilton-Buchanan) 1822

Genus: Aspidoparia Heckel 1843

18. Aspidoparia morar (Hamilton-Buchanan) 1822

Genus: Barilius (Hamilton-Buchanan) 1822

19. Barilius bendelisis (Hamilton-Buchanan) 1822

Genus: Rasbora Bleeker 1860

20. Rasbora daniconius (Hamilton-Buchanan) 1822

Order: Osteoglossiformes

Family: Notopteroidae 
Genus: Notopterus (Lacepede) 1800

21. Notopterus notopterus (Pallas) 1767

Order: Perciformes

Family: Anabantidae

Genus: Anabas Cuvier and Cloquet 1816

22. Anabas testudineus (Bloch) 1785

Family: Belontidae

Genus: Colisa Cuvier 1831

23. Colisa fasciatus (Schneider) 1801

Family: Channidae

Genus: Channa Scopoli 1777

24. Channa orientalis (Bloch and Schneider) 1801

25. Channa punctatus (Bloch) 1785

26. Channa striatus (Bloch) 1785

Family: Gobiidae

Genus: Glossogobius Gill 1839

27. Glossogobius giuris (Hamilton-Buchanan) 1822

Family: Chandidae

Genus: Chanda (Hamilton-Buchanan) 1822

28. Chanda nama (Hamilton-Buchanan) 1822

Genus: Paraambassis Bleeker 1874

29. Paraambassis ranga (Hamilton-Buchanan) 1822

Family: Nandidae

Genus: Nandus Valenciennes 1831

30. Nandus nandus (Hamilton-Buchanan) 1822

Order: Siluriformes

Family: Bagridae

Genus: Mystus Scopoli 1777

31. Mystus cavasius (Hamilton-Buchanan) 1822

32. Mystus tengara (Hamilton-Buchanan) 1822

33. Mystus vittatus (Bloch) 1797

Family: Claridae

Genus: Clarias Scopoli 1777

34. Clarias batrachus (Linnaeus) 1758

Family: Heteropneustidae

Genus: Heteropneustes Muller 1840

35. Heteropneustes fossilis Bloch 1785

Family: Schilbeidae

Genus: Clupisoma Swainson 1839

36. Clupisoma garua (Hamilton-Buchanan) 1822

Family: Siluridae

Genus: Ompok Lacepede 1803

37. Ompak bimaculatus (Bloch) 1797

Genus: Wallago Bleeker 1851

38. Wallago attu (Schneider) 1801

Order: Synbranchiformes

Family: Mastacembelidae

Genus: Macrognathus Lacepede 1800

39. Macrognathus aral (Bloch and Schneider) 1801

40. Macrognathus pancalus (Hamilton-Buchanan) 1822
Genus: Mastacembelus Scopoli 1777

41. Mastacembelus armatus (Lacepede) 1800

Family: Synbranchidae

Genus: Monopterus Lacepede 1800

42. Monopterus cuchia (Hamilton-Buchanan) 1822

Order Cypriniformes represented the highest species composition (46\%) while Perciformes and Siluriformes consisted $21 \%$ and $19 \%$ respectively. Similarly, family cyprinidae represented the highest species composition (40\%) followed by Bagridae, Channidae, Mastacembelidae consisting 31.5\%, 7\% and 7\% respectively.

The catch composition of individual fish species revealed that Nandus nandus, Puntius chola, $P$. sophore, Notopterus notopterus, Xenentodon cancila, Channa punctatus, Colisa fasciatus, Clarias batrachus and Heteropneustes fossilis were the dominant fish species of the reservoir (Table 1). High catch composition of these fishes suggested that the water quality of the reservoir was deteriorating gradually.

Of the 42 fish species, Aristichthys nobilis (Bighead carp), Ctenopharyngodon idella (Grass carp), Cyprinus carpio (Common carp) and Hypothalamichthys molitrix (Silver carp) were recorded only during the monsoon season, so presence of these exotic species in the reservoir may be due to carriage from nearby culture ponds by flood water. Their presence is not a good news for the indigenous fish diversity. Conservation program promoting diversity of local fish species should be taken into consideration and users group of this wetland should be aware regarding the capture fishery.

\section{Acknowledgements}

We are highly indebted to Prof. Dr. Umakant Ray Yadav, Head of the Department, Department of Environmental science, Tribhuwan University and Mr. Dharani Man Singh, Director of DoFD, Balaju for providing necessary guidance, invaluable suggestion and laboratory facilities for this work. We would like to thank Bina, Anju, Jham and Biraj for their continuous help during field activities. Besides, our heartfelt thanks go to Kamal Paswan, a local fisherman of Jagadispur, for his help in fish sampling and collection. 
Table 1. Catch composition of fish species

\begin{tabular}{l|l|l}
\hline Name of species & Total catch in number & Catch Composition (\%) \\
\hline Nandus nandus & 375 & 16.50 \\
Puntius chola & 283 & 12.45 \\
Puntius sophore & 228 & 10.03 \\
Notopterus notopterus & 197 & 8.67 \\
Xenentodon cancila & 136 & 5.98 \\
Channa punctatus & 135 & 5.94 \\
Colisa fasciatus & 86 & 3.78 \\
Clarias batrachus & 83 & 3.65 \\
Heteropneustes fossilis & 80 & 3.52 \\
Channa orientalis & 38 & 1.67 \\
Mystus vittatus & 38 & 1.67 \\
Mastacembelus armatus & 37 & 1.63 \\
Mystus cavasius & 35 & 1.54 \\
Salmostoma bacaila & 35 & 1.54 \\
Glossogobius giuris & 34 & 1.50 \\
Channa striatus & 29 & 1.28 \\
Macrognathus pancalus & 28 & 1.23 \\
Rasbora daniconius & 28 & 1.23 \\
Mystus tengara & 27 & 1.19 \\
Cirrhinus reba & 26 & 1.14 \\
Other & 315 & 13.88 \\
\hline
\end{tabular}

\section{References}

American Public Health Association (APHA), American Water works Association (AWWA), Water Environmental Federation (WEF). 1998. Standard methods for examination of water and waste water. (20 ${ }^{\text {th }}$ Edition). American Public Health Association, 1015 fifteenth street, NW, Washington D.C., USA.

Department of National Parks and Wildlife Conservation (DNPWC)/International Union for Conservation of Nature (IUCN). 2002. Information sheet on Ramsar wetlands (RIS) - Jagadispur Reservoir. DNPWC/ IUCN-Nepal.

Directorate of Fisheries Development (DoFD). 2007. Annual progress report. Fisheries Sub-sector, Directorate of Fisheries Development, Department of Agriculture, HMG, Hariharbhavan, Lalitpur, Nepal.

Jayaram, K.C. 1999. The freshwater fishes of the Indian region. Narendra Publishing House, Delhi, India. $551 \mathrm{pp}$.

Joshi, D. 2006. Ecological diversity of Jagadispur reservoir. In: World Ramsar Site, Jagadispur reservoir (Ed. N.P. Poudel): Published by Let's Save Lumbini-Kapilvastu Mission, Kapilvastu, Nepal (in Nepali). Pp. 1-24.

Kafe, G. 2008. Ramsar Sites of Nepal. (Version 1.1: Oct $27,2008)$.
Ng, H.H. 2006. The identity of Pseudechenis sulcata (McClelland) with description of two new species of Rheophitic cat fish (Teleostei:Sissoridae). Zootaxa 1254:45-68.

Ng, H.H. and D.R. Edds. 2004. Batasio macronotus, a new species of Bagrid cat fish from Nepal (Teleostei:Bagridae). Ichthyological Exploration Freshwaters 15(4):295-307.

Ng, H.H. and D.R. Edds. 2005a. Two new species of Erethistoides (Teleostei:Erethistidae) from Nepal. Ichthyological Exploration Freshwater 16 (3):239248.

Ng, H.H. and D.R. Edds. 2005b. Two new species of Pseudechensis rheophilic, cat fish (Teleostei:Sisoridae) from Nepal. Zootaxa 1047:1-19.

Rajbanshi, K.G. 2005. Review on current taxonomic status and diversity of fishes in Nepal. Occasional paper. No. 10. Royal Nepal Academy of Science and Technology. 41 pp.

Saund, T.B. and J. Shrestha. 2007. Fish and benthic fauna in Kulekhani reservoir. Nepal Journal of Science and Technology 8:63-68.

Shrestha, J. 1981. Fishes of Nepal. Curriculum Development Centre, Tribhuvan University, Kathmandu, Nepal. 
Shrestha, J. 1995. Enumeration of the fishes of Nepal. HMG Nepal/Government of Netherlands, Biodiversity Profiles Project. Publication No. 10.

Shrestha, J. 2001. Taxonomic revision of fishes of Nepal. Environment and agriculture. In: Biodiversity, agriculture and pollution in South Asia. (Eds. P.K. Jha et al.). ECOS, Kathmandu. Pp. 171-180.

Shrestha, J. 2003. Taxonomic revision of fishes of Nepal. In: Cold water fisheries in the trans-Himalayan countries. FAO. Fisheries Technical Paper 431. Pp. 273-288.
Shrestha T.B. and B. Bhandari. 1992. Proceeding of the first meeting on wetland management in Nepal. IUCN and DNPWC, Kathmandu.

Shrestha T.K. 2008. Ichthyology of Nepal. A study of fishes of the Himalayan waters. Himalayan Ecosphere. Kathmandu, Nepal. Pp. 1-388.

World Wildlife Fund (WWF). 2009. The Eastern Himalayas where the worlds collide. New species discoveries. Living Himalayas Initiatives. Pp. 1-28. 